\title{
Potensi Suplementasi Resveratrol dalam Mengatasi Efek Negatif Hormon Tiroid pada Terapi Obesitas: Uji Preklinik
}

\author{
Rovina Ruslami, ${ }^{1}$ Renny Rosalita, ${ }^{2}$ Raesa Yolanda, ${ }^{2}$ Agnes Agustin, ${ }^{2}$ Sudigdoadi ${ }^{2}$ \\ ${ }^{1}$ Departemen Farmakologi dan Terapi Fakultas Kedokteran Universitas Padjadajaran, ${ }^{2}$ Program Studi Pascasarjana \\ Ilmu Kedokteran Dasar Fakultas Kedokteran Universitas Padjadajaran Bandung
}

\begin{abstract}
Abstrak
Terapi obesitas menggunakan hormon tiroid menurunkan berat badan dengan nyata, namun menyebabkan berbagai efek negatif seperti stres oksidatif, kerusakan DNA, dan muscle wasting. Penelitian ini bertujuan mengkesplorasi potensi resveratrol (RSV), polifenol alami yang mempunyai efek antioksidan, anti-inflamasi, dan antiobesitas. Uji preklinik dengan rancangan acak sederhana dilakukan di Lab Hewan Fakultas Kedokteran Universitas Padjadjaran menggunakan 40 ekor tikus Wistar yang diinduksi obesitas. Hewan model obesitas dialokasikan secara acak ke dalam dua kelompok selama periode Agustus-November 2014. Kelompok perlakuan mendapat hormon tiroid 3 (HT3) dan RSV, serta kelompok kontrol mendapat HT3 saja selama 14 hari. Hewan coba yang mendapat HT3 dan RSV memiliki bobot badan lebih besar (290,5 g vs $251 \mathrm{~g}, \mathrm{p}=0,016)$, massa otot lebih berat $(2,57 \mathrm{~g}$ vs $2,25 \mathrm{~g}, \mathrm{p}=0,036)$, indeks adiposit lebih kecil $(0,89 \%$ vs $1,02 \%, \mathrm{p}=0,026)$, dan area under the curve (AUC) gukosa lebih kecil (1.849,2 mg.mnt/dL vs 2.591,7 mg.mnt/dL, p<0,001) dibanding yang mendapat HT3 saja. Tidak terdapat perbedaan kadar MDA plasma $(0,49 \mathrm{nmol} / \mathrm{mL}$ vs $0,44 \mathrm{nmol} / \mathrm{mL}, \mathrm{p}=0,430)$ dan kerusakan DNA $(19,7$ pixel vs 22,0 pixel, $\mathrm{p}=0,657)$ pada kedua kelompok yang mungkin berhubungan dengan dosis dan lama pemberian resveratrol. Suplementasi resveratrol berpotensi mengatasi efek negatif hormon tiroid pada hewan model obesitas. Perlu penelitian lanjutan untuk mengetahui dosis optimal resveratrol sebagai antioksidan pada pengobatan obesitas menggunakan hormon tiroid. [MKB. 2016;48(1):51-7]
\end{abstract}

Kata kunci: Hormon tiroid, obesitas, resveratrol, uji preklinik

\section{Resveratrol Supplementation Potential in Managing Negative Effects of Thyroid Hormone during Obesity Treatment: a Pre-Clinical Trial}

\begin{abstract}
Treatment of obesity using thyroid hormone could give significant result in decreasing body weight, but it also causes various negative effects such as oxidative stress, DNA damage, and muscle wasting. This sudy aimed to explore the potential of resveratrol, a natural polyphenol, that has anti-oxidant, anti-inflammatory, and anti-obesity effects, in managing negative effects of thyroid hormone used as anti-obesity. A preclinical trial was conducted at the animal laboratory, Faculty of Medicine, Universitas Padjadjaran. Forty male Wistar rats underwent obesity induction before randomly allocated into intervention and control groups in August-November 2014. The intervention group received a 14-days of triiodothyronine (T3) and resveratrol (RSV), while the control group received T3 only. Obese rats treated with T3 and RSV were heavier (body weight of $290.5 \mathrm{~g}$ vs $251.0 \mathrm{~g}, \mathrm{p}<0.016$ ), had a heavier muscle mass (2.57 g vs $2.25 \mathrm{~g}$, p=0.036), smaller adipocyte index, $(0.89 \%$ vs $1.02 \%$, $\mathrm{p}=0.026)$ and smaller glucose area under the curve (AUC) (1,848.2 mg.mnt/dL vs 2,591.7 mg.mnt/dL, p<0.001) than those who were treated with T3 only. There was no significance difference in MDA plasma levels $(0.49 \mathrm{nmol} / \mathrm{mL} \mathrm{vs}$ $0.44 \mathrm{nmol} / \mathrm{mL}, \mathrm{p}=0.0430$ ) and DNA damage (19.7 pixel vs 22.0 pixel, $\mathrm{p}=0.657$ ) between groups, probably due to insufficient dosage of resveratrol. Our results indicate that resveratrol supplementation could counter negative effects of thyroid hormone used as anti-obesity in obese-rats model treated with T3. More research is needed to determine the adequate dosage of resveratrol to elicit anti-oxidant effect that could minimize the negative effects of thyroid hormone as anti-obesity. [MKB. 2016;48(1):51-7]
\end{abstract}

Key words: Obesity, preclinical trial, resveratrol, thyroid hormone

Korespondensi: Rovina Ruslami, dr., Sp.PD, Ph.D, Departemen Farmakologi dan Terapi Fakultas Kedokteran Universitas Padjadajaran, Jalan Prof. Eijkman No. 38 Bandung, mobile 081342340336, e-mail n. ruslami@unpad.ac.id 


\section{Pendahuluan}

Obesitas ialah selalu berkaitan dengan masalah klinis berupa sindrom metabolik kronik yang mempunyai morbiditas dan mortalitas yang tinggi. Hampir tiga dari empat kematian akibat penyakit kardiovaskular dan diabetes melitus berhubungan dengan obesitas yang terjadi di negara berkembang. Obesitas dapat menurunkan angka harapan hidup dan juga menyebabkan disabilitas sebesar 3-9\%. ${ }^{1}$

Pada obesitas terjadi suatu kondisi inflamasi kronik, resistensi insulin, dan stres oksidatif yang terjadi akibat pembesaran dan penumpukan sel adiposit. Sel adiposit akan melepaskan sitokin proinflamasi seperti tumor necrosis factor (TNF)-a dan interleukin (IL)-6 yang selanjutnya menimbulkan inflamasi, gangguan sinyal insulin, dan pembentukan reactive oxygen species (ROS) sehingga menyebabkan stres oksidatif. ${ }^{2}$

Hormon tiroid merupakan obat antiobesitas ke-5 tersering diresepkan di Amerika Serikat, terlepas dari berbagai pro dan kontra. ${ }^{3}$ Hormon tiroid menurunkan bobot badan lebih nyata dibanding dengan restriksi diet dan kalori saja oleh karena hormon tiroid meningkatkan termogenesis, basal metabolic rate (BMR), dan lipolisis. $^{4}$

Hormon tiroid juga mempunyai efek negatif sebagai obat antiobesitas. Penelitian pada hewan model obesitas memperlihatkan bahwa pemberian hormon tiroid suprafisiologis dapat menurunkan bobot badan secara bermakna, namun juga meningkatkan pembentukan ROS, menyebabkan stres oksidatif, dan kerusakan deoxyribonucleic acid (DNA). Selain itu, hormon tiroid dapat menyebabkan katabolisme protein (muscle wasting) yang diindikasikan dengan penurunan indeks adiposit yang tidak sejalan dengan penurunan bobot badan. Hormon tiroid juga tidak memperbaiki resistensi insulin yang terjadi pada obesitas. ${ }^{5}$

Oleh karena terjadi stres oksidatif yang merupakan efek negatif dari hormon tiroid, kemudian menimbulkan suatu pemikiran bahwa pemberian antioksidan eksogen itu diharapkan dapat mengurangi efek negatif hormon tiroid. Resveratrol merupakan suatu senyawa polifenol alami dan merupakan salah satu antioksidan yang juga dikenal mempunyai efek antiobesitas dan juga anti-inflamasi. ${ }^{6}$ Penelitian ini bertujuan mengeksplorasi potensi resveratrol di dalam mengurangi efek negatif hormon tiroid sebagai terapi obesitas.

\section{Metode}

Penelitian eksperimental dengan rancangan acak sederhana dilakukan di Laboratorium Hewan Fakultas Kedokteran Universitas Padjadjaran (FK Unpad) sesudah mendapatkan izin etik dari Komite Etik Penelitian Kesehatan FK Unpad. Objek penelitian adalah empat puluh ekor tikus jantan galur Wistar sehat (usia 8-10 minggu, bobot badan 150-200 gram). Setelah adaptasi selama 1 minggu, dilakukan induksi obesitas dengan pemberian diet tinggi lemak (49,2\% kalori dari lemak) dan propiltiourasil (PTU) $0,01 \%$ 0,5 mg/kgBB selama 10 minggu. Hewan coba dikatakan obesitas jika tercapai Indeks Lee $>0,3$ yang dihitung dengan rumus sebagai berikut: ${ }^{7}$

$$
\text { Indeks Lee }=\frac{\sqrt{\text { Berat Badan (gram) }}}{\text { Panjang Nasoanal }(\mathrm{cm})}
$$

Gambar 1 menunjukkan hewan coba sebelum dan sesudah induksi obesitas, sedangkan Gambar 2 memperlihatkan cara pengukuran panjang badan nasoanal untuk menghitung Indeks Lee. Terhadap hewan coba yang memenuhi kriteria obesitas dilakukan pengambilan sampel darah melalui vena ekor untuk mendapatkan data awal resistensi insulin \{melalui pengukuran area under the curve (AUC) glukosa \} dan kondisi stres oksidatif \{berupa kadar malondyl aldehyde (MDA) plasma dan kerusakan DNA\}.

Hewan coba obesitas dialokasikan secara acak ke dalam dua kelompok: 1) kelompok perlakuan yang mendapat hormon tiroid 3/ HT3/liothyronine (Cytomel ${ }^{(\mathrm{R})}$ ) dan resveratrol (RSV) dan 2) kelompok kontrol yang mendapat HT3 saja. HT3 (25 mg/100 mgBB/hari) dan RSV $(100 \mathrm{mg} / \mathrm{kgBB} / \text { hari })^{5,8}$ diberikan per oral selama 14 hari. Pada periode perlakuan ini diet yang diberikan kembali diet standar. Di akhir perlakuan, semua hewan coba kembali ditimbang bobot badannya, kemudian dikorbankan dengan pemberian ketamin dosis letal $400 \mathrm{mg} / \mathrm{kgBB}$. Selanjutnya, sampel darah diambil dari jantung, lalu dilakukan penimbangan massa otot dan jaringan adiposit.

Penimbangan massa otot skeletal adalah otot gastroknemius, soleus, dan tibialis anterior kanan hewan coba. Sampel otot itu terlebih dahulu disimpan dalam larutan formalin $10 \%$, ditimbang dengan timbangan digital 48 jam 


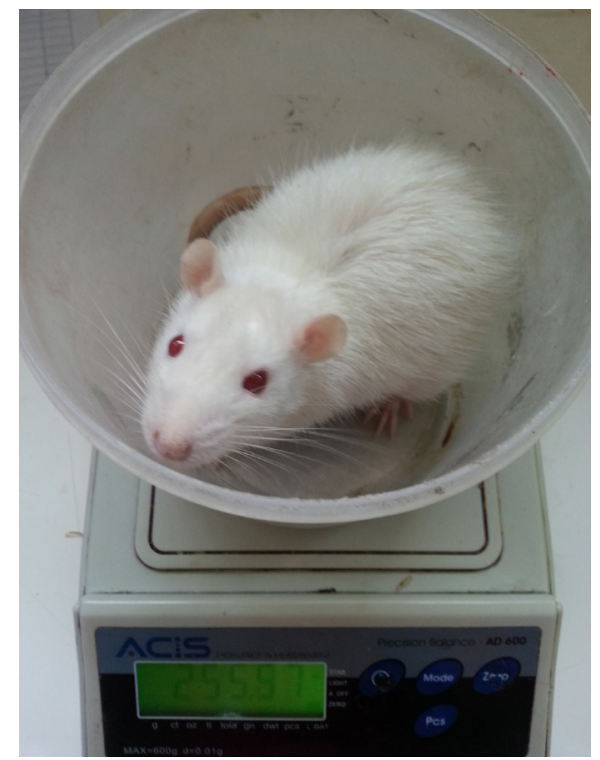

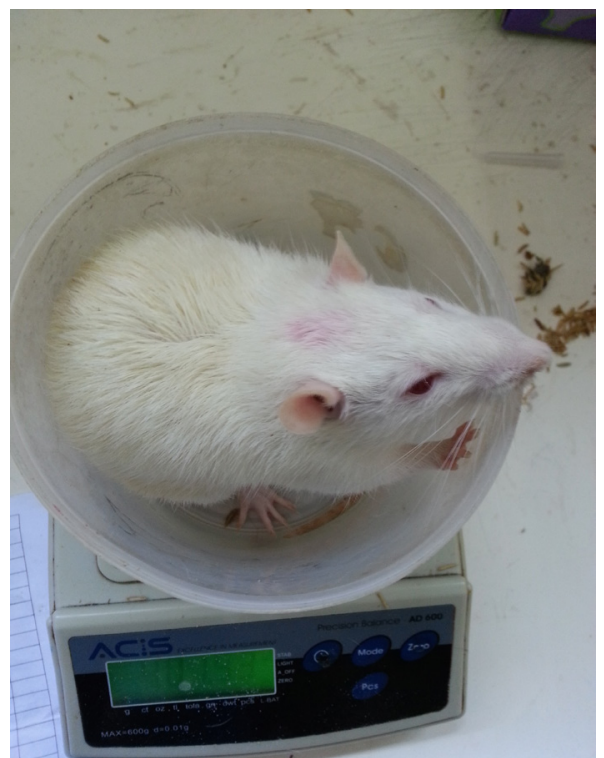

\section{Gambar 1 Hewan Coba Sebelum Induksi Obesitas (Kiri) dan Sesudah Induksi Obesitas (Kanan)}

sesudah pengambilan sampel.

Jaringan adiposit yang ditimbang adalah yang berasal dari tiga lokasi depot lemak, yaitu epididimis, retroperitoneum, dan viseral. Indeks adiposit adalah berat total lemak tubuh dibagi bobot badan akhir perlakuan dan dikali 100, dinyatakan dalam $\%{ }^{5}$

Penghitungan AUC glukosa didapat dengan melakukan tes toleransi insulin. Hewan coba dipuasakan 4-6 jam, kemudian disuntikkan insulin $1 \mathrm{U} / \mathrm{kgBB}$ intraperitoneal. Kadar gula darah diukur 7 kali, yaitu sesaat sebelum penyuntikan insulin, lalu setiap 5 menit selama

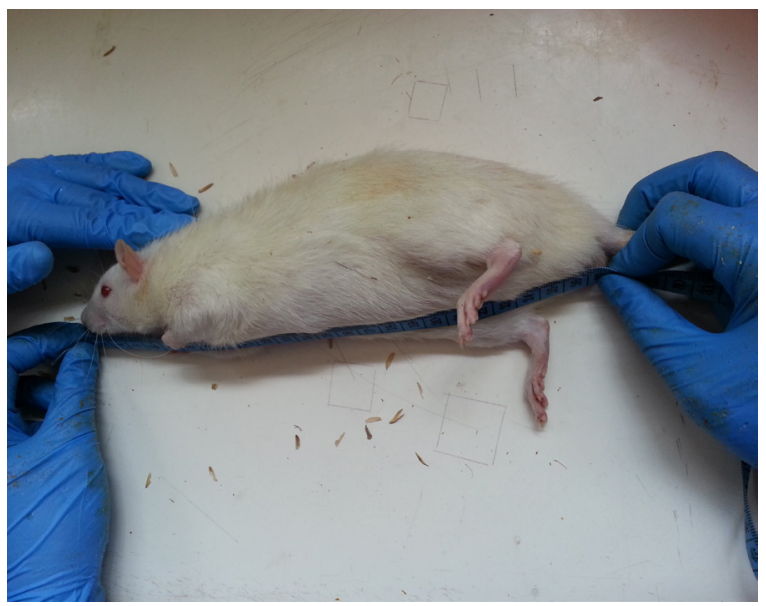

\section{Gambar 2 Pengukuran Panjang Nasoanal Hewan Coba}

30 menit dengan menggunakan glukometer. AUC glukosa dihitung dengan memplotkan ke-7 nilai gula darah serial, dihitung luas area di bawah kurva dengan metode penghitungan trapezoid. ${ }^{9}$

Kadar MDA plasma diukur dengan metode thiobarbituric acid reactive substance (TBARS) menggunakan spektrofotometri. ${ }^{11}$ Karena MDA bersifat tidak stabil, digunakan larutan standar tetraetoksipropan (TEP). Jika MDA dreaksikan dengan TBA akan membentuk larutan berwarna merah muda dan menyerap cahaya pada panjang gelombang $530 \mathrm{~nm}$. Sebanyak $2.000 \mu \mathrm{L}$ plasma sampel ditambahkan $1.000 \mu \mathrm{L}$ larutan TCA $20 \%$ dengan perbandingan 2:1:2. Campuran divorteks (1 menit), disentrifugasi $(3.000 \mathrm{rpm}$, 10 menit). Supernatan ditambahkan larutan TBA $0.67 \%$ sebanyak $2.000 \mu \mathrm{L}$ dan divorteks. Tabung diinkubasi pada waterbath (suhu $95-100^{\circ} \mathrm{C}, 10$ menit). Tabung reaksi kemudian didinginkan dalam bejana berisi air es. Hasil reaksi diukur absorbansinya dengan spektrofotometer pada panjang gelombang 532,5 $\mathrm{nm}$.

Pemeriksaan pada kerusakan DNA dilakukan menggunakan metode comet assay. Prinsip comet assay adalah lisis sel yang dilanjutkan dengan elektroforesis. Saat elektroforesis, fragmen DNA yang rusak akan meninggalkan badan sel membentuk ekor comet. Secara ringkas limfosit diisolasi dari sampel darah, kemudian kerusakan DNA dianalisis menggunakan OxiSelect comet assay kit (Cell Biolabs, USA). Sebanyak 50 nukleoid dari masing-masing sampel dianalisis mempergunakan software TriTek Comet Score 
Tabel 1 Karakteristik Dasar Hewan Coba Model Obesitas

\begin{tabular}{|c|c|c|c|}
\hline Karakteristik & $\begin{array}{c}\text { Perlakuan } \\
\text { (HT3 + RSV) } \\
\text { n = 19 }\end{array}$ & $\begin{array}{c}\text { Kontrol } \\
\text { (HT3) } \\
\text { n= 19 }\end{array}$ & Nilai p \\
\hline Bobot badan (gram) & $371,8(46,2)$ & $346,7(53,9)$ & $0,132 *$ \\
\hline Panjang badan $(\mathrm{cm})$ & $22,2(1,2)$ & $21,4(1,6)$ & $0,074 *$ \\
\hline Indeks Lee & $0,32(0,31-0,35)$ & $0,33(0,31-0,36)$ & $0,486^{* *}$ \\
\hline Tail moment (pixel) & $22,1(8,91)$ & $19,3(7,9)$ & $0,372 *$ \\
\hline AUC glukosa (mg.mnt/dL) & $3.347,2(695,3)$ & $3.370,9(794,3)$ & $0,923 *$ \\
\hline
\end{tabular}

Keterangan: Data disajikan dalam nilai rata-rata (simpangan baku) untuk data berdistribusi normal. Data disajikan dalam nilai median (min-maks) untuk data berdistribusi tidak normal. HT3=hormon tiroid; RSV=resveratrol; $\mathrm{n}=$ jumlah hewan coba; *uji- $t$ tidak berpasangan; *uji Mann-Whitney U

Freeware 1.6.1.13. Kerusakan DNA dinilai dengan parameter tail moment, yaitu hasil perkalian tail length dengan tail DNA \%.,11

Data ditampilkan secara deskriptif dalam bentuk rata-rata atau median bergantung pada normalitas distribusi data (diuji dengan SaphiroWilk). Analisis statistik dilakukan dengan uji-t tidak berpasangan untuk data yang terdistribusi normal atau uji Mann-Whitney U untuk data tidak terdistribusi normal. Hasil uji statistik dikatakan bermakna jika nilai $\mathrm{p}<0,05$.

\section{Hasil}

Dari 40 ekor hewan coba, 2 ekor mati sebelum dirandomisasi; seluruh hewan yang tersisa (38 ekor) berhasil mencapai kriteria obesitas dan kemudian dirandomisasi untuk masuk ke dalam kelompok perlakuan atau kelompok kontrol. Pada masa intervensi, 7 ekor mati (5 ekor dari kelompok perlakuan dan 2 ekor dari kelompok kontrol) sehingga berjumlah 14 ekor pada kelompok perlakuan dan 17 ekor pada kelompok kontrol. Induksi obesitas selama 10 minggu memperlihatkan peningkatan bobot badan yang signifikan dengan rata-rata 369,7 g. AUC glukosa rata-rata adalah 3.359,1 mg.mnt/dL, sedangkan tail moment rata-rata adalah 20,6 pixel.

Karakteristik dasar pada hewan coba model obesitas dapat dilihat pada Tabel 1. Tidak terdapat perbedaan pada kedua kelompok mengenai data kondisi fisik (bobot badan dan Indeks Lee), tingkat kerusakan DNA (panjang

Tabel 2 Efek Resveratrol terhadap Bobot Badan, Massa Otot, Indeks Adiposit, AUC Glukosa, MDA Plasma, dan Tail Moment pada Hewan Coba Model Obesitas yang Mendapat Terapi Hormon Tiroid

\begin{tabular}{|c|c|c|c|}
\hline Karakteristik & $\begin{array}{c}\text { Perlakuan } \\
\text { (HT3 + RSV) } \\
\text { n=14 }\end{array}$ & $\begin{array}{c}\text { Kontrol } \\
\text { (HT3) } \\
\text { n=17 }\end{array}$ & Nilai p \\
\hline Bobot badan (gram) & $290,5(206-232)$ & $251,0(187-320)$ & $0,016^{*}$ \\
\hline Massa otot (g) & $2,57(0,45)$ & $2,25(0,33)$ & $0,036^{* *}$ \\
\hline Indeks adiposit (\%) & $0,89(0,08)$ & $1,02(0,18)$ & $0,026^{* *}$ \\
\hline AUC glukosa (mg.mnt/dL) & $1.848,2(326,7)$ & $2.591,7(518,6)$ & $0,000^{* *}$ \\
\hline MDA plasma $(\mathrm{nmol} / \mathrm{mL}) \mathrm{d}$ & $0,49(0,08-2,57)$ & $0,44(0,17-2,23)$ & $0,430^{*}$ \\
\hline Tail moment (pixel)g & $19,7(13,5)$ & $22,0(10,1)$ & $0,657^{* *}$ \\
\hline
\end{tabular}

Keterangan: Data disajikan dalam nilai rata-rata (simpangan baku) untuk data berdistribusi normal. Data disajikan dalam nilai median (min-maks) untuk data berdistribusi tidak normal. HT3=hormon tiroid; RV=resveratrol; n=jumlah hewan coba; ${ }^{\mathrm{d}}$ data tersedia 14 pada kelompok perlakuan dan 16 pada kelompok kontrol; ${ }^{\mathrm{g}}$ data tersedia 9 pada kelompok perlakuan dan 13 pada kelompok kontrol; ${ }^{*}$ uji Mann-Whitney U; ${ }^{* *}$ uji-t tidak berpasangan 

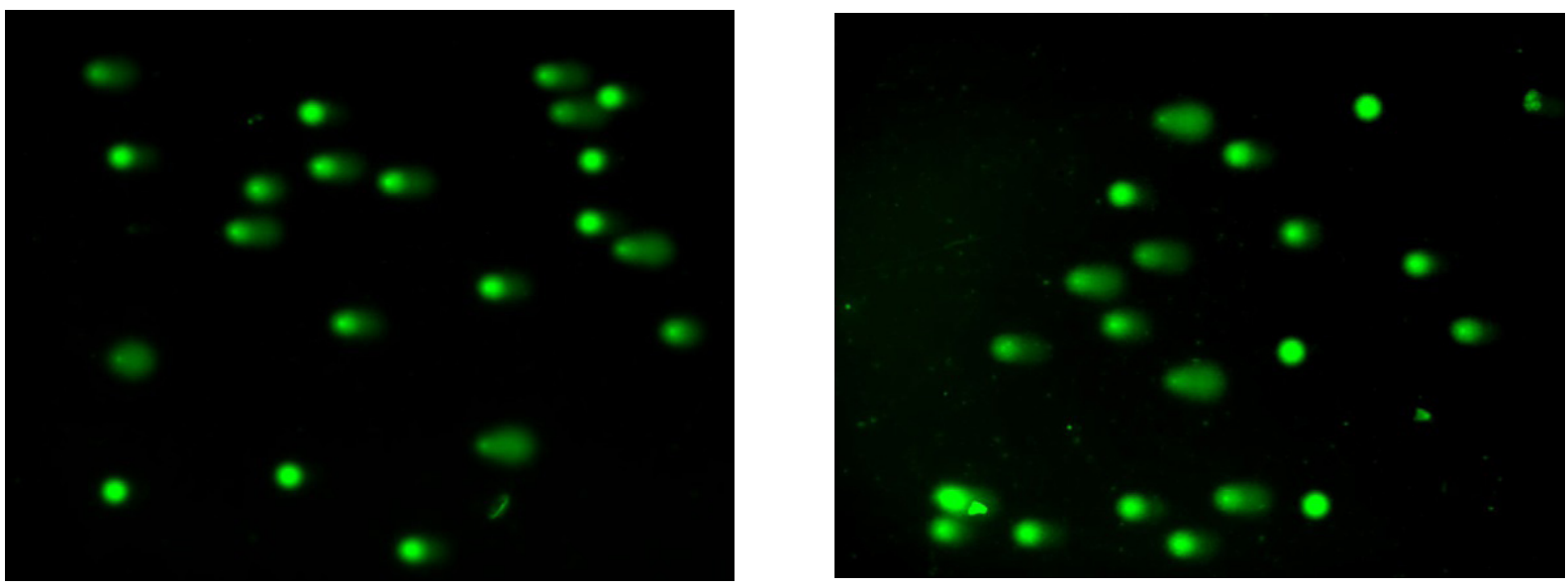

Gambar 3 Nukleoid Limfosit Hasil Pemeriksaan Comet Assay. Hewan Coba Model Obesitas Sesudah Intervensi

Keterangan: A=kelompok perlakuan (HT3+resveratrol), B=kelompok kontrol (HT3 saja)

comet tail moment), dan tingkat resistensi insulin (AUC glukosa) yang memperlihatkan bahwa randomisasi berhasil. Data kadar MDA plasma tidak dapat ditampilkan karena gangguan teknis di laboratorium, sedangkan pemeriksaan MDA memerlukan sampel darah segar.

Setelah perlakuan, bobot badan hewan coba pada kelompok yang mendapatkan HT3 dan RSV secara bermakna lebih berat dibanding dengan yang hanya mendapat HT3 (290,5 g vs 251,0 g; $\mathrm{p}=0,016)$. Seperti halnya bobot badan, massa otot hewan coba yang mendapat HT3 dan RSV secara bermakna lebih berat dibanding dengan yang mendapat HT3 saja $(2,57 \mathrm{~g}$ vs $2,25 \mathrm{~g}$; $\mathrm{p}=0,036)$. Indeks adiposit pada hewan coba yang mendapat HT3 dan RSV secara bermakna lebih kecil jika dibanding dengan yang mendapat HT3 saja $(0,89 \%$ vs $1,02 \%$; $p=0,026)$ (Tabel 2 ).

Pada pemeriksaan resistensi insulin, AUC glukosa rata-rata hewan coba yang mendapat HT3 dan RSV secara bermakna lebih rendah bila dibanding dengan yang mendapat HT3 saja (1.848,2 mg.mnt/dL vs 2.591,7 mg.mnt/dL, $\mathrm{p}<0,001$; Tabel 2). Jika dibanding dengan AUC glukosa hewan coba yang mendapat HT3 saja, AUC glukosa rata-rata sesudah mendapat terapi HT3 selama 2 minggu lebih rendah dibanding dengan sebelum terapi HT3 (2.591,7 mg.mnt/dL vs 3.370,9 mg.mnt/dL, $\mathrm{p}<0,001$ ).

Efek RSV terhadap stres oksidatif dan juga kerusakan DNA dilihat dengan menilai kadar MDA plasma dan penghitungan tail moment. Tidak didapatkan perbedaan kadar MDA plasma antara kedua kelompok $(0,49 \mathrm{nmol} / \mathrm{mL}$ vs 0,44 $\mathrm{nmol} / \mathrm{mL}, \mathrm{p}=0,0430)$. Gambar 3 memperlihatkan gambaran fragmen DNA yang telah rusak akan meninggalkan badan sel yang membentuk ekor comet. Analisis statistik memperlihatkan bahwa tidak terdapat perbedaan tail moment rata-rata pada kedua kelompok $(19,7$ pixel vs 22,0 pixel; $\mathrm{p}=0,657$ ) yang mengimplikasikan bahwa tidak terdapat perbedaan kerusakan DNA kelompok yang mendapatkan terapi kombinasi HT3 dan RSV dengan kelompok yang mendapatkan HT3 saja.

\section{Pembahasan}

Penelitian ini melanjutkan penelitian preklinik yang memperlihatkan bahwa pemberian HT3 sebanyak $25 \mu \mathrm{g} / 100 \mathrm{~g} /$ hari selama 14 hari pada tikus Wistar model obesitas efektif dalam menurunkan bobot badan, namun menyebabkan kerusakan DNA karena stres oksidatif. HT3 juga tidak mampu memperbaiki resistensi insulin pada obesitas. ${ }^{5}$ Penelitian ini didasari pemikiran perlunya penambahan antioksidan eksogen untuk dapat meminimalisir efek samping negatif yang timbul dari pemberian HT3. Resveratrol adalah antioksidan alami yang poten dalam menghambat pembentukkan ROS. ${ }^{2}$ Resveratrol juga mempunyai efek antiobesitas. Penelitian ini merupakan penelitian pertama yang mampu megeksplorasi potensi suplementasi RSV terapi obesitas menggunakan HT3.

Suplementasi resveratrol dapat memberikan perbaikan yang signifikan terhadap resistensi insulin, bobot badan, massa otot, dan indeks adiposit. Hewan coba yang mendapat HT3 akan mengalami penurunan bobot badan yang sangat signifikan, namun tidak sejalan dengan 
penurunan indeks adiposit. ${ }^{5}$ Hal ini diduga karena terjadi peningkatan katabolisme protein yang menyebabkan muscle wasting dengan menurunnya massa otot skelet.

Pemberian RSV secara bersamaan dengan HT3 mampu menurunkan bobot badan secara bermakna, namun pada penelitian ini bobot badan hewan coba yang mendapatkan HT3 dan RSV lebih berat dibanding dengan yang hanya mendapatkan HT3. Indeks adiposit pada kelompok perlakuan juga lebih kecil dibanding dengan kelompok kontrol dan massa otot pada kelompokperlakuanlebihberatdibandingdengan kelompok kontrol. Data ini memperlihatkan pemberian RSV mempertahankan massa otot skelet dan menurunkan jumlah adiposit.

Fenomena di atas berkaitan dengan kerja RSV yang meningkatkan aktivitas silent mating type information regulation (SIRT)-1 melalui jalur inhibisi nuclear factor kappa $\beta$ (NFк $\beta)$ dan forkhead box $O$ (FoxO) sehingga menghambat degradasi protein otot skeletal serta atrofi otot bahkan meningkatkan fungsi dan juga kekuatan otot. ${ }^{12}$ Lebih lanjut, RSV menurunkan jumlah adiposit dengan cara menurunkan adipogenesis serta mampu menginduksi apoptosis melalui peningkatan aktivitas SIRT-1 yang menekan ekspresi dari peroxisome proliferator-activated receptor (PPAR)- $\gamma$ dan juga menginhibisi jalur (PI3K)/Akt sehingga meningkatkan ekspresi gen $\mathrm{Bac} / \mathrm{Bcl}-2{ }^{5,13}$ Hasil ini memperlihatkan hal positif dari penambahan RSV karena tujuan utama pengobatan obesitas adalah menurunkan massa lemak, bukan menurunkan massa otot.

Berbeda dengan penelitian terdahulu, ${ }^{6}$ pada penelitian ini pemberian HT3 selama 14 hari mampu memperbaiki resistensi insulin. Keadaan ini mungkin disebabkan oleh lamanya induksi obesitas; pada penelitian terdahulu induksi obesitas lebih lama (20 minggu). Lebih lanjut, pada penelitian ini penambahan RSV lebih memperbaiki resistensi insulin yang terlihat dari lebih rendahnya AUC glukosa rata-rata pada kelompok yang mendapat HT3 dan RSV jika dibanding dengan kelompok yang mendapat HT3 saja $(p<0,001)$. Perbaikan resistensi insulin oleh RSV diduga melalui peningkatan aktivitas SIRT-1 dan adenosine monophosphate-activated protein kinase (AMPK) sehingga menghambat glukoneogenesis hepatik, meningkatkan ambilan glukosa pada otot skeletal, dan merangsang pengeluaran insulin melalui sel- $\beta$ pankreas. ${ }^{14,15}$

Walau secara fenotip (bobot badan, massa otot, indeks adiposit, serta AUC glukosa) suplementasi RSV pada terapi obesitas dengan HT3 memperlihatkan hasil yang signifikan, namun efek ini tidak terlihat pada pengukuran parameter stres oksidatif (kadar MDA plasma) dan kerusakan DNA yang ditimbulkan oleh HT3 $(p>0,05)$. Beberapa dugaan yang dapat menjelaskan hasil tersebut antara lain berkaitan dengan dosis dan lama pemberian RSV serta besar sampel.

Belum diketahui berapa dosis optimal RSV sebagai antioksidan untuk mengatasi efek negatif HT3 dalam terapi obesitas. Secara umun resveratrol memperlihatkan efek bifasik, dosis kecil memperlihatkan efek antioksidan, sedangkan dosis tinggi malah memperlihatkan efek pro-oksidan. ${ }^{16}$ Bukti lain memperlihatkan bahwa efek antioksidan RSV bersifat dosedependent, semakin tinggi dosis RSV akan dapat memberikan efek antioksidan yang semakin besar. ${ }^{17}$ Rentang dosis RSV untuk antioksidan yang telah diujikan sampai saat ini sangat lebar, pada uji preklinik berkisar $5-500 \mathrm{mg} / \mathrm{kgBB} / \mathrm{hari}$ dan pada uji klinik 5-5.000 mg/hari. ${ }^{18}$

Bioavailabilitas RSV sangat rendah karena mengalami first pass metabolism. ${ }^{19}$ Pemberian RSV per oral $100 \mathrm{mg} / \mathrm{kgBB} / \mathrm{hari}$ pada tikus Wistar mampu memperlihatkan bioavailabilitas yang rendah dengan kadar plasma 1,3 mM. ${ }^{20}$ Pemilihan dosis $100 \mathrm{mg} / \mathrm{kgBB} /$ hari pada penelitian ini berdasarkan penelitian Aydin dkk. ${ }^{8}$ yang mengeksplorasi efek RSV terhadap stres oksidatif pada hewan coba model sepsis Pada penelitian ini tidak dilakukan pengukuran kadar RSV dalam plasma.

Penjelasan lainnya adalah jumlah sampel yang kurang dari jumlah sampel minimal (32 sampel). Pada awal penelitian sudah diantisipasi mengenai kemungkinan terjadi drop-out, namun karena kematian hewan coba yang tidak terduga menyebabkan hanya terdapat 30 sampel untuk data MDA dan 22 sampel untuk data kerusakan DNA. Besar sampel yang kurang menyebabkan lemahnya power suatu penelitian untuk dapat memperlihatkan effect size yang diperkirakan.

Simpulan, bahwa suplementasi resveratrol berpotensi dalam mengatasi efek negatif hormon tiroid pada terapi obesitas pada hewan model obesitas. Diperlukan penelitian yang lebih lanjut mengenai dosis dan lama pemberian resveratrol yang adekuat sebagai antioksidan yang dapat meminimalisir efek negatif hormon tiroid pada pengobatan obesitas.

\section{Daftar Pustaka}

1. Ng M, Fleming T, Robinson $\mathrm{M}$, Thomson B, Graetz N, Margono C, dkk. Global, regional, 
and national prevalence of overweight and obesity in children and adults during 19802013: A systematic snalysis for the global burden of disease study 2013. Lancet. 2014; 384(9945):766-81.

2. Park SJ, Ahmad F, Philp A, Baar K, Williams T, Luo H, dkk. Resveratrol ameliorates aging-related metabolic phenotypes by inhibiting camp phosphodiesterases. Cell. 2012;148(3):421-33.

3. Krotkiewski M. Thyroid hormones and treatment of obesity. Int J Obesity. 2000; 24(Suppl 2):S116-9.

4. BiondiB, Wartofsky L. Treatment with thyroid hormone. Endocr Rev. 2014;35(3):433-512.

5. Sibio MT, Luvizotto RAM, Olimpio RMC, Correa CR, Marino J, Oliveira M, dkk. A comparative genotoxicity study of a supraphysiological dose of triiodothyronine (T3) in obese rats subjected to either calorierestricted diet or hyperthyroidism. Plos One. 2013;8(2):e56913.

6. Baile CA, Yang JY, Rayalam S, Hartzell DL, Lai CY, Andersen C, dkk. Effect of resveratrol on fat mobilization. Ann N Y Acad Sci. 2011;1215(1):40-7.

7. Campos KE, Volpato GT, Calderon IM, Rudge MV, Damasceno DC. Effect of obesity on rat reproduction and on the development of their adult offspring. Braz J Med Biol Res. 2008;41(2):122-5.

8. Aydin S, Bacanli M, Taner G, Sahin T, Basaran AA, Basaran N. Protective effects of resveratrol on sepsis-induced DNA damage in the lymphocytes of rats. Hum Exp Toxicol. 2013;32(10):1048-57.

9. Borai A, Livingstone C, Kaddam I, Ferns G. Selection of the appropriate method for the assessment of insulin resistance. BMC Med Res Methodol. 2011;11(1):158.

10. Wills E. Evaluation of lipid peroxidation in lipids and biochem toxicology. Dalam: Snell K, Mullock B, penyunting. A practical approach.
Oxford: IRL Press; 1987. hlm. 127-52.

11. Liao W, McNutt MA, Zhu WG. The comet assay: a sensitive method for detecting dna damage in individual cells. Methods. 2009;48(1):46-53.

12. Naylor AJD. Cellular effects of resveratrol in skeletal muscle. Life Sci. 2009;84(1920):637-40.

13. Rayalam S, Della-Fera MA, Baile CA. Synergism between resveratrol and other phytochemicals: implications for obesity and osteoporosis. Mol Nutr Food Res. 2011;55(8):1177-85.

14. Shang J, Chen LL, Xiao FX, Sun H, Ding HC, Xiao H. Resveratrol improves non-alcoholic fatty liver disease by activating ampactivated protein kinase. Acta Pharmacol Sin. 2008;29(6):698-706.

15. Houtkooper RH, Pirinen E, Auwerx J. Sirtuins as regulators of metabolism and healthspan. Moll Cell Biol. 2012;13(1):225-38.

16. Mukherjee S, Dudley JI, Das DK. Dosedependency of resveratrol in providing health benefits. Dose Response. 2010;8(4):478500.

17. Acquaviva R, Russo A, Campisi A, Sorrenti V, Giacomo CD, Barcellona ML, dkk.. Antioxidant activity and protective effect on DNA cleavage of resveratrol. J Food Sci. 2002;67(1):137-41.

18. Crandall JP, Barzilai N. Exploring the promise of resveratrol: where do we go from here? Diabetes. 2013;62(4):1022-3.

19. Smoliga JM, Vang O, Baur JA. Challenges of translating basic research into therapeutics: resveratrol as an example. J Gerontol A Biol Sci Med Sci. 2012;67(2):158-67.

20. Peltz L, Gomez J, Marquez M, Alencastro F, Atashpanjeh N, Quang T, dkk. Resveratrol exerts dosage and duration dependent effect on human mesenchymal stem cell development. PLoS One. 2012;7(5):e37162. 